\title{
THERAPEUTIC PROPERTIES OF WHEY USED AS FERMENTED DRINK
}

\author{
T. Kar*; A.K. Misra \\ Department of Dairy Bacteriology, Faculty of Dairy Technology, West Bengal University of Animal and \\ Fishery Sciences, Mohanpur, Nadia, West Bengal, India
}

Submitted: August 05, 1998; Returned to authors for corrections: September 29, 1998; Approved: June 16, 1999.

\begin{abstract}
Bioconversion of whey for preparation of beverage was standardized by utilizing yoghurt cultures. The product, wheyghurt drink, made with $4 \%$ yoghurt cultures inoculated in deproteinized whey $(4.8 \%$ lactose, $0.66 \%$ ash, $0.46 \%$ fat and $0.40 \%$ protein adjusted to $\mathrm{pH} 6.4$ ) and incubated at $42^{\circ} \mathrm{C}$ for $8 \mathrm{~h}$ had all the technological requisite and dietetic criteria required in the product. The factors affecting the antibacterial activity of wheyghurt drink against Escherichia coli, Staphylococcus aureus, Shigella dysenteriae and Bacillus cereus were determined. There was a significant variation $(\mathrm{P}<0.05)$ in the antibacterial activity of wheyghurt drink with different levels of inoculum $(1,2,4$, and $8 \%$ ) and concentration of sugar at 37,42 and $45^{\circ} \mathrm{C}$. Incubation at $42^{\circ} \mathrm{C}$ with $4 \%$ culture in whey exhibited highest inhibitory activity. The product stored up to 5 days under refrigeration was of acceptable organoleptic quality and requisite amount of microbial population $\left(10^{8} \mathrm{cfu} / \mathrm{ml}\right)$ to be potentially beneficial.
\end{abstract}

Key words: whey, yoghurt, antibacterial activity

\section{INTRODUCTION}

The bioconversion of whey is an interesting process from the view point of human nutrition, especially for therapeutic purposes, in regard to economy, and with advantage for reducing environment pollution. Ancient Greeks as well as Hippocrates, in 460 B.C., prescribed cheese whey for the assortment of human ailments. Use of Lactobacillus delbrueckii subsp., bulgaricus and Streptococcus thermophilus in the manufacturing of yoghurt have been extensively studied throughout the world. Regular intake of this product looks effective both in prevention and treatment of various illness in man viz. gastrointestinal disorders (14), hypercholesterolemia (10), antitumoral $(3,14)$, reduced protein allergencity, treatment of vaginal discharge, a cure for osteoporosis etc. (10). Although yoghurt bacteria can grow well in whey $(5,23,27)$ use of these organisms in the preparation of whey drink is still limited.

The present communication includes a report on the preparation of wheyghurt drink, a fermented whey beverage prepared by using $L$. delbrueckii subsp. bulgaricus $\mathrm{W}$ and $S$. thermophilus $\mathrm{H}$ as culture organisms, assessment of its antibacterial activity as well as its acceptability and survival of the culture organisms in the gastrointestinal segments of wheyghurt drink fed rats.

\footnotetext{
* Corresponding author. Mailing address: Department of Dairy Bacteriology, Faculty of Dairy Technology, West Bengal University of Animal and Fishery Sciences, Mohanpur, Nadia, 741252, West Bengal, India
} 


\section{MATERIALS AND METHODS}

\section{Preparation of whey}

Whey was prepared by heating pooled cow milk to $82^{\circ} \mathrm{C}$ and $2 \%$ citric acid solution was added at the rate of $2 \mathrm{gm}$. Per $\mathrm{kg}$ of milk. Complete coagulation was effected within one minute and the whey filtered muslim cloth is popularly known as chhana whey in India where the coagulum chhana is used as a base material for traditional sweetmeats. Whey obtained was adjusted to $\mathrm{pH} 5.5$ using $10 \% \mathrm{NaHCO}_{3}$ solution and was heated at $100^{\circ} \mathrm{C}$ for 10 minute with $0.4 \%$ $\mathrm{CaCl}_{2}$ and kept undisturbed overnight at room temperature and filtered to obtain deproteinized whey (20). The product was then polished aseptically through washed diatomaceous earth built up as one half inch cake on a No. 54 Whatman filter paper placed in Buckner funnel (19). The average composition of whey was $4.8 \%$ lactose, $0.60 \%$ ash, $0.46 \%$ fat and $0.4 \%$ protein.

\section{Source and Maintenance of Cultures}

Lactobacillus delbrueckii subsp. bulgaricus W and Streptococcus thermophilus $\mathrm{H}$ along with the test cultures of pathogenic organisms viz. Bacillus cereus, Escherichia coli, Shigella dysenteriae and Staphylococcus aureus were obtained from the National Collection of Dairy Organisms, National Dairy Research Institute, Karnal, India. Lactobacillus delbrueckii subsp. bulgaricus W. and Streptococuss thermophilus $\mathrm{H}$ were maintained in sterile deproteinized whey peptone broth (8), with the following composition: peptone, $1 \mathrm{gm}$; sodium chloride, $0.5 \mathrm{gm}$ and whey $100 \mathrm{ml}$. $\mathrm{pH}$ of the media was maintained at 7.0. This whey medium was transferred to standard corning screw capped tubes $(15 \times 125 \mathrm{~mm})$ by filling upto neck and were sterilized by steaming for $30 \mathrm{~min}$ on three consecutive days. The stock cultures were activated by three successive transfers at $48 \mathrm{~h}$ interval. The pathogenic cultures were maintained on nutrient agar slants (oxoid) and were activated by three successive transfers at $24 \mathrm{~h}$ intervals in nutrient broth.

\section{Preparation of Wheyghurt Drink}

A Schematic diagram conceptualizing the process employed for the production of wheyghurt drink using L. delbrueckii subsp. bulgaricus $\mathrm{W}$ and $\mathrm{S}$. thermophilus $\mathrm{H}$ cultures for direct consumption is showed in Fig. 1. The effect of some factors such as i) size of inoculum, viz. 1, 2, 4 and $8 \%$. ii) incubation temperature viz. 37,42 and $45^{\circ} \mathrm{C}$ iii) concentration of sucrose viz. $0,6,8,10,12$ and $16 \%$ and iv) storage at refrigeration temperature $\left(5^{\circ} \mathrm{C}\right)$ for $1,2,5,10$ and 15 days - on the antibacterial activity of the drink were also examined.

\section{Analysis}

Wheyghurt drink was analyzed for titratable acidity (6), volatile acidity (15), lactic acid (4) and $\beta$ $\mathrm{D}$-galactosidase activity (13). The antibacterial activity of the product was estimated by the modified cup agar assay technique (7). Culture filtrates (or cell free extracts) were collected by centrifugation at $3000 \mathrm{rpm}$ for 15-20 min. These were passed through Seitz filter separately. Wells of $5 \mathrm{~mm}$ diameter were made on solidified nutrient agar (inoculated with the pathogenic test organisms) in each plate, and $50 \mu 1$ of the cellfree extract introduced transferred to wells. The plates were incubated without inverting at $37^{\circ} \mathrm{C}$ for $18-24 \mathrm{~h}$ and the diameters of inhibition zones were statistically evaluated by analysis of variance (29).

Samples of wheyghurt drink were subjected to sensory evaluation by a panel of 7 judges 9-point hedonic scale (2) and analysed statistically by 2 -way classification (29).

For survival of wheyghurt drink organisms in the intestine of rats 10 weanling male albino rats $\geq 21$ and $\leq 28$ days old were used. Each animal was fed with $15 \mathrm{~g}$ of rat feed synthetic ration containing $20 \%$ casein, $50 \%$ sucrose, $24 \%$ hydrogenated vegetable oil, $2 \%$ cod liver oil, $4 \%$ USP salt mixture, one multivitamin capsule (500 mg Pfizer) per $\mathrm{kg}$. diet and $20 \mathrm{ml}$ wheyghurt drink as preliminary diet for 7 days immediately prior to lights being extinguished. After $16 \mathrm{~h}$, food cups and any remaining food were removed from the cages, the rats fasting for $8 \mathrm{~h}$ before being fed again. One the $8^{\text {th }}$ and final day of the experiment, the animals except for one which served as a fasted control were provided with only 20 to 24 $\mathrm{g}$ of specific test meal (wheyghurt drink) and given 30 min to consume it. At intervals of 60,120 and $180 \mathrm{~min}$. after the meal animals were anesthetized with ether, weighed and its abdomen opened and contents of the stomach, duodenum, and jejunum were sampled after injecting and mixing 1.0 c.c. sterile saline $(0.85 \% \mathrm{NaCl})$ into the clamped-off segments and aspirating with a sterile 5 c.c. syringe and a 22 gauge needle. Serial ten-fold dilutions of the aspirated contents were then prepared with sterile saline, and pour plated in duplicate on Elliker Agar (12). 
Therapeutic properties of whey

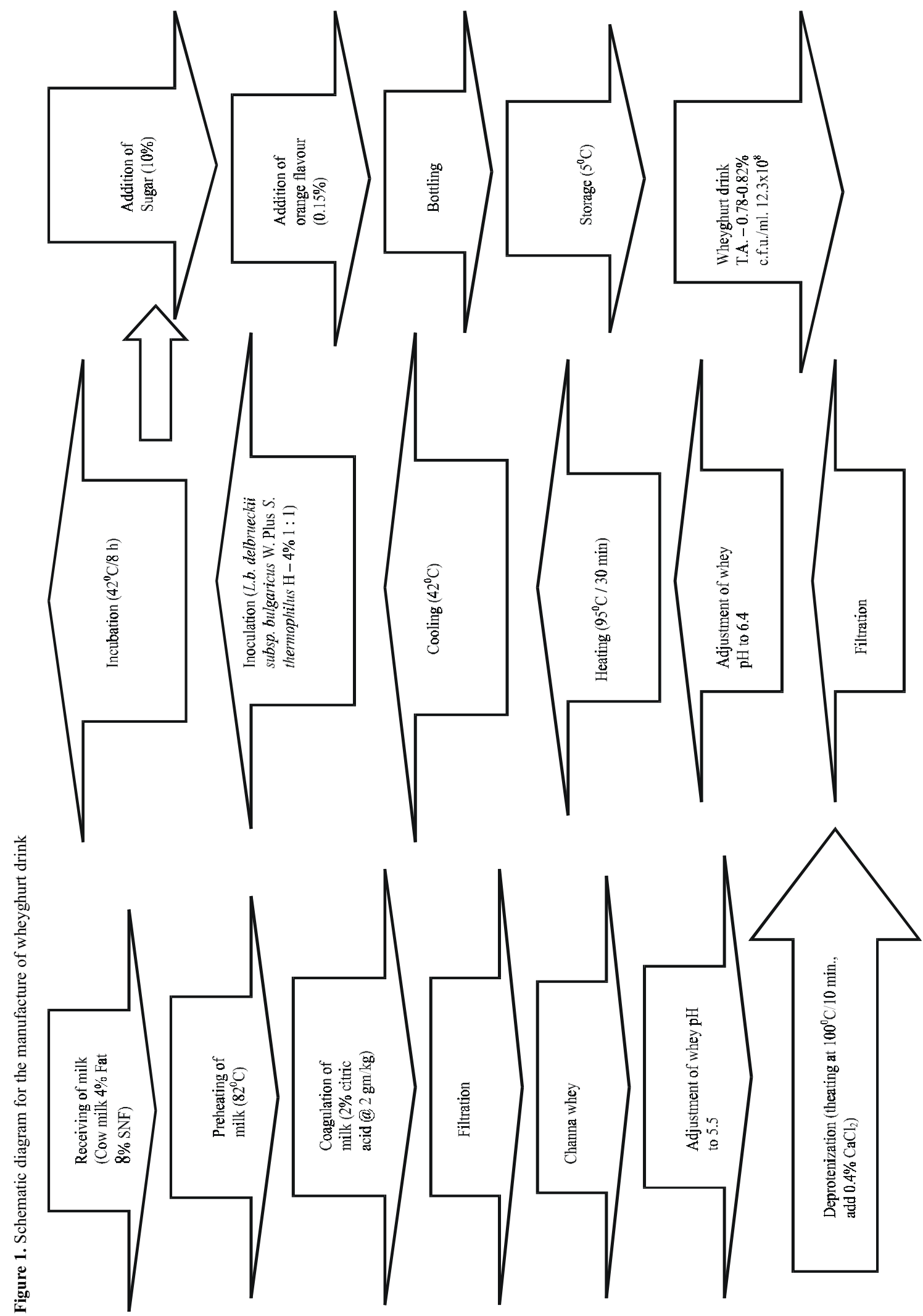




\section{RESULTS AND DISCUSSION}

\section{Characteristics of the Product}

The procedure shown in Fig.1 was adopted for the preparation of wheyghurt drink using $4 \%$ mixed culture of $L$. delbrueckii subsp. bulgaricus $\mathrm{W}$ and $S$. thermophilus $\mathrm{H}$ in the ratio of $1: 1$. The final product had a titratable acedity of $0.78-0.82 \%, 2.0$ to 2.4 $\mathrm{ml}$. of volatile acidity, $204-207 \mu \mathrm{g} / \mathrm{ml}$ lactic acid, $\beta$ D-galactosidase activity of $2.30 \mu \mathrm{mol}$ of lactose hydrolysed $/ \mathrm{gm} / \mathrm{h}$., mild acidic flavour, antibacterial activity against all the four test organisms viz. $E$. coli, S. aureus, Shigella dysenteriae and B. cereus (inhibitory zone 8 to $10 \mathrm{~mm}$ ) and a viable count of $12.3 \times 10^{8}$ c.f.u./ml. Rasic and Kurmann, 1979, recommended acidity level of 0.78 to $0.85 \%$ for yoghurt preparation (25). Considering that the minimum acidity of $0.7 \%$ is specified for yoghurt by the International Dairy Federation (1969), the product showed a desirable acidity level (16). Tramer, 1973 (31); Rasic and Kurmann, 1979 (25) and Singh, 1983 (28) recommended an inoculum of $1-3 \%$ for the preparation of yoghurt, but in the present study $4 \%$ inoculum was used due to low total solid content in whey. The use of high inoculum ensures a normal course of lactic acid fermentation and restrict unfavourable growth conditions as residual antibiotic, lack of growth substances etc. (22). Viable lactic acid bacteria population in the range of $10^{8}$ to $10^{9} \mathrm{cell} / \mathrm{ml}$. of the fermented product causes successful seeding in intestine during consumption $(17,21,30)$ and the product prepared according to the schematic chart (Fig. 1) satisfied the condition.

\section{Effect of the Levels of Inoculum}

The effect of 1, 2, 4 and $8 \%$ inoculum of $L$. delbrueckii subsp. bulgaricus $\mathrm{W}$ and $S$. thermophilus
$\mathrm{H}(1: 1)$ on the antibacterial acitivity against four test organisms is depicted in Table 1. There was a significant variation $(\mathrm{P}<0.05)$ in the antibacterial activity due to change in level of inoculum. A 4\% inoculum showed maximum antibacterial activity against $S$. aureus $(10 \mathrm{~mm}$.) and $B$. cereus $(8 \mathrm{~mm}$.), although antibacterial activity against these two organisms decreased at inoculum level of $8 \%(9 \mathrm{~mm}$. for $S$. aureus and $7 \mathrm{~mm}$. for B. cereus). Pette and Lolkema (24) reported that higher inoculum level increases the Lactobacillus content of yoghurt. Single strain culture of $L$. delbreneckii subsp. bulgaricus W showed lower antibacterial activity against $S$. aureus and $B$. cereus in comparison to $S$. thermophilus $\mathrm{H}$ in channa whey. The product exhibited similar antibacterial activity against the other two test organisms viz. E. coli and Shigella dysenteriae at all inoculum level.

\section{Effect of Incubation Temperature}

The data on the effect of different incubation temperature viz. $37^{\circ} \mathrm{C}, 42^{\circ} \mathrm{C}$ and $45^{\circ} \mathrm{C}$ on the antibacterial activity of wheyghurt drink is presented in Table 2 . At $45^{\circ} \mathrm{C}$ weak $(6 \mathrm{~mm}$. inhibition zone against E.coli, S. aureus and Shigella dysenteriae) or no antibacterial activity (against $B$. cereus) was visible, in despite of maximum titratable acidity $(0.82 \%$ against $0.74 \%$ and $0.80 \%$, respectively, at 37 and $42^{\circ} \mathrm{C}$ ) was reported at this temperature. The data indicated that production of antibacterial substances was not related to titratable acidity $(9,26)$. Maximum antibacterial activity of the product was obtained at $42^{\circ} \mathrm{C}$, probably due to increased total cell count of $12.5 \times 10^{8}$ c.f.u. $/ \mathrm{ml}$. promoted by temperature, leading to increase in the production of antibacterial substances.

Table 1. Effect of level of inoculum on the antibacterial activity of wheyghurt drink

Culture Combination: Lactobacillus delbrueckii subsp. bulgaricus W and Streptococus thermophilus H (1: 1)

\begin{tabular}{ccccccc}
\hline \multirow{2}{*}{$\begin{array}{c}\text { Percent } \\
\text { Inoculum }\end{array}$} & $\begin{array}{c}\text { Titratable } \\
\text { Acidity (LA \%) }\end{array}$ & $\begin{array}{c}\text { Total cell } \\
\text { count (c.f.u./ml) }\end{array}$ & E. coli & S. aureus & $\begin{array}{c}\text { Shigella } \\
\text { dysenteriae }\end{array}$ & B. cereus \\
\cline { 4 - 7 } & 0.64 & $2.89 \times 10^{7}$ & 8.5 & 9.0 & 8.5 & 7.5 \\
2 & 0.74 & $3.47 \times 10^{7}$ & 9.0 & 8.5 & 9.0 & 7.0 \\
4 & 0.80 & $12.30 \times 10^{8}$ & 9.0 & 10.0 & 9.0 & 8.0 \\
8 & 0.90 & $21.0 \times 10^{8}$ & 9.0 & 9.0 & 9.0 & 7.0 \\
\hline
\end{tabular}

* Included dimateter of well (5 mm.) (amount of supernatant in well $0.05 \mathrm{ml}$ ). 


\section{Effect of Sugar Concentration}

When sweetened wheyghurt drink was prepared using different concentrations of sugar $(0,6,8,10$, 12 and 16\%) it was observed that as the level of sugar addition increased there was very slight change in the titratable acidity, total viable count and antibacterial activity of the product upto $10 \%$ level of sucrose (Table 3 ) but at $12 \%$ sucrose level the changes were significant $(\mathrm{P}<0.05)$. Addition of $16 \%$ sucrose exhibited no antibacterial activity against any of the four test organisms with a low acidity $(0.68 \%)$ and viable count $\left(3.2 \times 10^{8}\right.$ c.f.u. $\left./ \mathrm{ml}\right)$. Tramer (31) also reported that during preparation of yoghurt addition of sugar should not allow total solids to exceed $22 \%$ to avoid severe inhibition of yoghurt starters. However, it was observed that wheyghurt drink with $10 \%$ level of sucrose was excellent in taste with optimum titratable acidicy $(0.78 \%)$ and recommended viable count $\left(12.1 \times 10^{8}\right.$ c.f.u. $\left./ \mathrm{ml}\right)$.

\section{Effect of Storage at Refrigeration Temperature}

Refrigerated storage $\left(5^{\circ} \mathrm{C}\right)$ of wheyghurt drink for 15 days indicated that the storage time increased beyond 5 days caused decrease in the antibacterial activity against the four organisms tested and with sharp decline after 10 days (Table 4$)$. The total viable count decreased from $12.5 \times 10^{8}$ c.f.u. $/ \mathrm{ml}$. to $54 \mathrm{x}$ $10^{6}$ c.f.u./ml. after 15 days of storage. The product was very sour in taste after 10 days of storage and was not liked by the consumers (sensory score 4.90). Kumar et al., (18) also reported a highly acidic product from fermentation of whey with yoghurt culture. Average sensory evaluation of wheyghurt drink by a panel of seven judges showed that maximum average sensory score of 6.50 in nine point hedonic scale was obtained after $24 \mathrm{~h}$. of storage. The product was acceptable on the basis of mouthfeel, overall appearance and optimum level of acidity up to 5 th day of storage (sensory score 6.00 ).

\section{Survival of Wheyghurt Drink Microflora in the Rat Intestine}

The total viable cell counts of the gastrointestinal segments (stomach, jejunum and duodenum) of wheyghurt drink fed rats at intervals of 60,120 and $180 \mathrm{~min}$. after meal are presented in Table 4. The count remained elevated until 2 to $3 \mathrm{~h}$ after ingestion of wheyghurt drink thereby demonstrating significant survival and potential metabolic activity in the upper gastrointestinal tract of the animals. Highest count

Table 2. Effect of incubation temperature on antibacterial activity of wheyghurt drinks

\begin{tabular}{|c|c|c|c|c|c|c|}
\hline \multirow{2}{*}{$\begin{array}{c}\text { Incubation } \\
\text { Temperature }\left(0^{\circ} \mathrm{C}\right)\end{array}$} & \multirow{2}{*}{$\begin{array}{l}\text { Acidity } \\
\text { (LA \%) }\end{array}$} & \multirow{2}{*}{$\begin{array}{c}\text { Total cell } \\
\text { count (c.f.u. } / \mathrm{ml})\end{array}$} & \multicolumn{4}{|c|}{ Dia. of zone of Inhibition (mm.)* } \\
\hline & & & E. coli & S. aureus & $\begin{array}{c}\text { Shigella } \\
\text { dysenteriae }\end{array}$ & B. cereus \\
\hline 37 & 0.74 & $11.2 \times 10^{8}$ & 9.5 & 9.5 & 8.5 & 7.5 \\
\hline 42 & 0.80 & $12.5 \times 10^{8}$ & 9.0 & 10.0 & 9.0 & 8.0 \\
\hline 45 & 0.82 & $6.8 \times 10^{8}$ & 6.0 & 6.0 & 6.0 & - \\
\hline
\end{tabular}

* Included well dimateter of well (5 mm.) (amount of supernatant in well $0.05 \mathrm{ml}$ ).

Table 3. Effect of concentration of sugar on antibacterial activity of wheyghurt

\begin{tabular}{ccccccc}
\hline \multirow{2}{*}{$\begin{array}{c}\text { Concentration of } \\
\text { Sugar (Percent) }\end{array}$} & $\begin{array}{c}\text { Acidity } \\
\text { (LA \%) }\end{array}$ & $\begin{array}{c}\text { Total cell } \\
\text { count (c.f.u./ml) }\end{array}$ & \multicolumn{3}{c}{ Dia. of zone of Inhibition $(\mathrm{mm} .)^{*}$} \\
\cline { 4 - 7 } & 0.80 & $12.5 \times 10^{8}$ & 9.0 & 10.0 & 9.0 & 8.0 \\
\hline 0 & 0.80 & $12.5 \times 10^{8}$ & 9.0 & 10.0 & 9.0 & 8.0 \\
6 & 0.80 & $12.3 \times 10^{8}$ & 9.0 & 9.5 & 9.0 & 8.0 \\
8 & 0.78 & $12.1 \times 10^{8}$ & 9.0 & 9.5 & 9.0 & 8.0 \\
10 & 0.74 & $10.8 \times 10^{8}$ & 8.0 & 9.0 & 8.0 & 7.5 \\
12 & 0.68 & $3.2 \times 10^{8}$ & - & - & - & - \\
16 & & & & & & Shigella cereus \\
\end{tabular}

* Well diameter included ( $5 \mathrm{~mm}$.)

- :No inhibition observed. 
Table 4. Effect of storage at refrigeration temperature $\left(5^{\circ} \mathrm{C}\right)$ on bacterial growth, antibacterial activity and sensory score of wheyghurt drink

\begin{tabular}{ccccccc}
\hline \multirow{2}{*}{$\begin{array}{c}\text { No. of Days } \\
\text { of Storage }\end{array}$} & $\begin{array}{c}\text { Total cell } \\
\text { count (c.f.u./ml) }\end{array}$ & E. coli & S. aureus & Shigella & $\begin{array}{c}\text { B. cereus } \\
\text { dysenteriae }\end{array}$ & Average Sensory \\
score.
\end{tabular}

* Well diameter included $(5 \mathrm{~mm}$.)

Table 5. Viable cell counts of gastrointestinal segments of rat given special dietary treatment.

$($ Treatment $=$ Rat feed (sucrose) $+20 \mathrm{ml}$. Wheyghurt Drink as preliminary meal and Wheyghurt Drink as test meal)

\begin{tabular}{lccc}
\hline Gastrointestinal & \multicolumn{3}{c}{ Log Counts of Viable Cells per ml. } \\
\cline { 2 - 4 } Segements & $60 \mathrm{~min}$. & $120 \mathrm{~min}$ & $180 \mathrm{~min}$ \\
\hline Stomach & 7.83 & 6.60 & 3.41 \\
Jejunum & 4.90 & 7.45 & 5.20 \\
Duodenum & 4.20 & 5.17 & 5.58 \\
\hline
\end{tabular}

was observed in the stomach whereas lowest count was observed in the duodenum. This may be due to the effect of bile salt in the duodenum which altered permeability of the bacterial cells and thereby resisted the growth of the organisms. Acott and Labuza (1) have shown that yoghurt microflora were capable of surviving simulated gastric digestion where Goodenough and Kleyn (13) have demonstrated gastrointestinal survival of yoghurt organisms in vivo up to $3 \mathrm{~h}$. after feeding.

\section{CONCLUSION}

Wheyghurt drink made with yoghurt cultures showed potential therapeutic properties, and optimum sensory qualities with a shelf life of 5 days. The yoghurt microflora survived in the gastrointestinal tract, and the mass effect combined with the antagonistic activity against undesirable organisms represents an important factor for the utilization of fermented whey drink preparation with both dietetic and technological properties.

\section{RESUMO}

\section{Propriedades terapêuticas de soro de leite usado como bebida fermentada}

A bioconversão de soro de leite para preparação de bebida foi padronizada utilizando culturas de iogurte. O produto feito com culturas de iogurte a $4 \%$, inoculadas em soro desproteinizado (lactose $4,8 \%$; cinzas, $0,66 \%$; gordura $0,46 \%$ e proteína $0,40 \%, \mathrm{pH} 6,4)$, incubado a $42^{\circ} \mathrm{C}$ por $8 \mathrm{~h}$, apresentou todos os requisitos tecnológicos e critérios dietéticos requeridos para o produto. Os fatores que afetam a atividade antibacteriana do produto contra Escherichia coli, Staphylococcus aureus, Shigella dysenteriae e Bacillus cereus foram determinados. Houve uma variação significativa na atividade antibacteriana do produto contendo diferentes níveis de inóculo (1, 2, 4 e 8\%) e concentração de açúcar a 37,42 e $45^{\circ} \mathrm{C}$. Incubação a $42^{\circ} \mathrm{C}$ com cultura a $4 \%$ no soro apresentou a maior atividade inibitória. $\mathrm{O}$ produto armazenado até 5 dias em refrigeração apresentou características organolépticas aceitáveis e microrganismos em quantidade adequada $\left(10^{8} \mathrm{ufc} / \mathrm{ml}\right)$ para ser considerado benéfico.

Palavras-chave: soro de leite, iogurte, atividade antibacteriana

\section{REFERENCES}

1. Acott K M, Labuza TP. Yoghurt: Is it truly Adelle's B vitamin factory ? Food Prod Dev 6, 51-56, 1972.

2. Amerine MA, Pangborn RM, Roessler EM. A Principle of Sensory Evaluation of Foods. Academic Press, New York, 1967.

3. Ayebo AD, Shahani KM, Dam R. Antitumor component (s) of yoghurt: Fractionation. J Dairy Sci 64, 2318-2323, 1981. 
4. Barker SB, Summerson WH. Colorimetric determination of lactic acid in biological material. J Biol Chem 138, 535-538, 1941.

5. Beaulieu Y, Girard N, Melinard J, McCallum J, Goulet J. Growth and fermentative activity of lactic thermophilic bacteria after cultivation in whey permeate and synthetic media. J Dairy Sci 75 (Suppl 1), 132, 1992.

6. BIS. Indian Standard: 1479 (Part I) Methods of Test for Dairy Industry. Rapid Examination of Milk. Indian Standard Institution. Manak Bhavan, New Delhi, India, 1960.

7. BSI. Methods of Microbial Examination for Dairy Pruposes. British Standards Institution, British Standards House, London, UK, BS: 4285, 1968.

8. Chalmers CH. Bacteria in Relation to the Milk Supply. $4^{\text {th }}$ ed, Edward Arnold (Publishers) Ltd, London, 263, 1962.

9. Chopra R, Gandhi DN. Factors affecting the antibacterial activity of fermented beverage prepared from sweet cream buttermilk. Indian J Dairy Sci 42, 406-408, 1989.

10. Deeth HC, Tamime AY. Yoghurt: nutritive and therapeutic aspects. J. Food Protec. 44, 78-86, 1981.

11. De S. Outlines of Dairy Technology $1^{\text {st }} \mathrm{ed}$, Oxford University Press, New Delhi, India, 418-419, 1980.

12. Elliker PR, Anderson AW, Hannesson G. An agar culture media for lactic acid streptococci and lactobacilli. J Dairy Sci. 39, 1611-1612, 1956.

13. Goodenough ER, Kleyn DH. Influence of viable yoghurt microflora on digestion of lactose by the rat. J Dairy Sci 59, 601-604, 1976.

14. Gurr MI. The nutritional role of cultured dairy products. Can Inst Food Sci Technol 17, 57-64, 1984.

15. Hempeniens WL, Liska BJ. Methods for determining volatile acids in cultured dairy products. J Dairy Sci 51, 221-222, 1968.

16. International Dairy Federation. Int. Scand. FIL-IDF, 192, 1969.

17. Kim SH. Characterization of lactobacilli and bifidobacteria as applied to dietary adjuncts. Cult Dairy Prod J 8, 5-6, 1988.

18. Kumar R, Patil GR, Rajor RB. Development of Lassi type cultured beverage from cheese whey. Asian J Dairy Res 6, 121-124, 1987.
19. Lundstedt E. Citrated whey starters. I. Growth patterns of starters and their aroma bacteria when cultivated in rennet whey or cottage cheese whey, citrated with the addition of five percent trisodium citrate pentahydrate. J Dairy Sci 45, $1320-1326,1962$.

20. Mathur BN, Kumar A, Ladkani BG. Clarification of whey for the preparation of beverages. Indian J Dairy Sci 39, 340 - 342., 1986.

21. Misra AK. Studies on Bifidobacterium bifidum based fermented milk products. Ph D thesis, Bidhan Chandra Krishi Viswavidyalaya, Mohanpur, Nadia, WB, India, 1988.

22. Mocquot G, Hull C. The selection and use of some microorganisms for the manufacture of fermented and acidified milk products. J Soc Dairy Technol 23, 130-142, 1970.

23. Parente E, Zottola EA. Growth of thermophilic starters in whey permeate media. J Dairy Sci 74, 20-28, 1991.

24. Pette JW, Lolkema H. Yoghurt IV: factors influencing the proportion of streptococci and lactobacilli in a yoghurt culture. Ibid 5, 14-26, 1951.

25. Rasic JL Kurmann JÁ. Fermented Milk Products vol I Yoghurt Scientific grounds, technology, manufacture and preparations. Technical Data Pub. House, Copenhagen, Denmark, 1979.

26. Reddy GV, Shahani KM. Isolation of an antibiotic from Lactobacillus bulgaricus. J Dairy Sci 54, 748-752, 1971.

27. Ritter P. Growth and acid producing characteristics of several lactic acid bacteria cultivated in milk and wheys which were treated in different way. XIIIth Int Dairy Congr 3, 1391-1393, 1953.

28. Singh J. Lactic cultures for yoghurt. Indian Dairyman 35 , $633-634,1983$.

29. Snedecor GW, Cochran WG. Statistical Methods. Oxford and IBH Publ Co, Calcutta, India, 1967.

30. Tanaka M, Iwanami T, Arai K, Nakagawa K, Joko K, Muroto I, Yamaduki M. Cultured milk production method. German Federal Republic Pat DE, 3048-438, 1982.

31. Tramer J. Yoghurt cultures. J Soc Dairy Technol 26, 16-21, 1973. 